\title{
E-COMMERCE DAN SISTEM INFORMASI AKUNTANSI SEBAGAI FAKTOR PENDORONG PENGAMBILAN KEPUTUSAN MAHASISWA AKUNTANSI UNTUK BERWIRAUSAHA
}

\author{
Nurabiah \\ Fakultas Ekonomi dan Bisnis Universitas Mataram \\ nurabiah@unram.ac.id \\ Herlina Pusparini \\ Fakultas Ekonomi dan Bisnis Universitas Mataram \\ h.pusparini@unram.ac.id \\ Yusli Mariadi \\ Fakultas Ekonomi dan Bisnis Universitas Mataram \\ yuslimariadi@unram.ac.id
}

Article History:

Received: 28 Maret 2021

Revised: 26 April 2021

Accepted: 26 April 2021
Abstract: The purpose of this study was to analyze the effect of e-commerce and the use of accounting information systems in making entrepreneurial decisions. This study used the Technology Acceptance Model (TAM) and contingency theory where this theory will be able to explain the acceptance of a technology and the relationship between the application of the used of accounting information systems and e-commerce to influence the behavior of students majoring in Accounting in entrepreneurship. The population in this study were active accounting undergraduate students who have taken entrepreneurship courses and accounting information systems for PTN and PTS in the city of Mataram. The sampling technique used purposive sampling method, data were collected by 142 distributed questionnaires. Data analysis techniques used the PLS 3.0 smart application. The results of the study indicate that the e-commerce has a positive and insignificant effect on decision making of accounting students in entrepreneurship and the accounting information system has a significant positive effect on decision making of accounting students in entrepreneurship. With the application of acceptance model technology and contingency theory to explain the acceptance of a technology and the relationship between the application of accounting information systems and e-commerce to influence students majoring in accounting in entrepreneurship.

Abstrak: Tujuan penelitian ini adalah untuk 
menganalisis pengaruh e- commerce dan penggunaan Sistem Informasi Akuntansi dalam pengambilan keputusan untuk berwirausaha. Penelitian ini menggunakan teori Technology Acceptance Model (TAM) dan contingency theory dimana theory ini akan mampu menjelaskan penerimaan sebuah teknologi dan hubungan keterkaitan antara penerapan penggunaan sistem informasi akuntansi dan e-commerce untuk mempengaruhi perilaku mahasiswa jurusan Akuntansi dalam berwirausaha. Populasi dalam penelitian ini adalah mahasiswa S1 akuntansi aktif yang sudah mengambil mata kuliah kewirausahaan dan sistem informasi akuntansi PTN dan PTS di Kota Mataram. Teknik pengambilan sampel menggunakan metode purposive sampling, jumlah responden sebanyak 142 mahasiswa S1 Akuntansi se Kota Mataram. Pengumpulan data menggunakan kusioner. Untuk menguji hipotesis digunakan teknik Partial Least Square (PLS) menggunakan aplikasi smart PLS 3.0. Hasil penelitian menyatakan bahwa e- commerce berpengaruh positif tidak signifikan terhadap pengambilan keputusan mahasiswa akuntansi dalam berwirausaha dan Sistem informasi akuntansi berpengaruh positif signifikan terhadap pengambilan keputusan mahasiswa akuntansi dalam berwirausaha. Dengan penerapan technology acceptance model dan contingency theorymenjelaskan penerimaan sebuah teknologi dan hubungan keterkaitan antara penerapan penggunaan sistem informasi akuntansi dan ecommerce untuk mempengaruhi perilaku mahasiswa jurusan akuntansi dalam berwirausaha.

Keywords: e-commerce, accounting information systems, entrepreneurship. Kata Kunci: e-commerce, sistem informasi akuntansi, berwirausaha

\section{PENDAHULUAN}

Angka pengangguran terdidik di Indonesia setiap tahun semakin melonjak pesat. Berdasarkan data Badan Pusat Statistik (BPS) selama tiga tahun terakhir dari tahun 2017 s.d. 2019 bahwa pengangguran terdidik mengalami kenaikan naik yaitu lulusan Diploma I/II/III mengalami kenaikan sebesar $8.5 \%$ dan lulusan Sarjana/Universitas juga mengalami kenaikan sebesar 25\% (BPS, 2020). Ada sejumlah faktor yang dinilai menyebabkan peningkatan pengangguran terdidik tersebut. Salah satunya, pendidikan rendah cenderung lebih menerima pekerjaan apa pun. Hal ini berbeda dengan mereka yang pendidikannya lebih tinggi. Dan 
ini bukan saja pekerjaan rumah bagi pemerintah, tetapi juga bagi pihak perguruan tinggi.

Salah satu cara untuk mengurangi pengangguran tersebut adalah mempersiapkan lulusan yang berjiwa wirausaha yang mampu menyediakan lapangan kerja bagi diri sendiri maupun orang lain (Suryaman, 2006). Dan memberikan perhatian lebih kepada mahasiswa yang memiliki niat untuk berwirausaha.

Apalagi sekarang kemajuan teknologi dapat memberikan kemudahan dalam mengembangkan bisnis dan memberikan peluang bisnis bagi wirausaha untuk melakukan penjualan secara lebih luas, praktis dan mendapatkan keuntungan yang lebih besar. Wirausaha bisa menggunakan e-commerce sebagai bagian dalam pengembangan bisnisnya. Hal yang dilakukan wirausaha cukup membuat web di internet untuk memasarkan produknya dan juga tidak perlu mengeluarkan biaya yang mahal untuk memperluas promosi dalam bisnisnya. Banyak promosi yang dilakukan para wirausaha seperti menggunakan media sosial. Media sosial merupakan sebuah fenomena baru yang telah mengubah cara lingkungan bisnis beroperasi (Prihadi \& Susilawati, 2018).

Selama melakukan transaksi harus memiliki catatan data yang dapat digunakan untuk seorang wirausaha dalam pengambilan keputusan. Catatan data tersebut merupakan sumber informasi yang harus milki oleh wirausaha. Salah satu penyaji informasi adalah akuntansi, dimana akuntansi merupakan alat untuk menginformasikan keadaan suatu perusahaan atau organisasi (Pramiswari \& Dharmadiaksa, 2017). Sebagai alat dalam mengolah data akuntansi dan keuangan, akuntansi membutuhkan suatu sistem informasi yang dapat menyampaikan informasi kepada pihak yang membutuhkan.

Sistem Informasi Akuntansi (SIA) adalah kumpulan sumber daya (manusia dan peralatan) pada suatu organisasi yang dirancang sedemikian rupa yang berisi tentang informasi keuangan dan informasi yang telah dikumpulkan agar memudahkan dalam mengambil keputusan (Bodnar \& Hopwood, 2013). Dengan menggunakan sistem akuntansi pngolahan data yang dilakukan dapat terpercaya keakuratannya. Romney \& Steinbert (2017) juga menyatakan bahwa penerapan teknologi sistem informasi akuntansi di perusahaan dapat memberikan nilai tambah bagi pengguna yang pada akhirnya berdampak positif pada peningkatan kinerja. Begitu juga dengan hasil penelitian Margareta (2019), Wahyuni \& Diana (2020), Wulandari et al., (2020) menyatakan bahwa penggunaan sistem informasi akuntansi terhadap pengambilan keputusan untuk berwirausaha berpengaruh positif dan signifikan.

Salah satu program pemerintah yakni meningkatkan jumlah wirausahawan untuk mendukung visi Indonesia menjadi Negara maju di tahun 2045. Salah satu indikator Negara maju adalah terciptanya lapangan pekerjaan yang lebih banyak. Hal ini tidak mungkin terjadi jika 
para lulusan dari perguruan tinggi bergantung pada lapangan pekerjaan yang dibuka oleh pemerintah. Untuk mewujudkan visi tersebut, Indonesia harus menambah jumlah pengusaha (wirausahawan) yang tidak hanya bergantung pada aspek sumber daya alam tapi juga mampu bergerak di bidang industri. Untuk mencetak wirausahawan, bisa dilakukan dari tingkat perguruan tinggi. Melalui pembelajaran e-commerce dan sistem informasi akuntansi yang selaras dengan dunia kerja.

Tujuan dari penelitian ini adalah menganalisis pengaruh ecommerce dan system informasi akuntansi terhadap pengambilan keputusan Mahasiswa Akuntansi dalam berwirausaha. Penelitian tentang ini sudah cukup banyak dilakukan tetapi indikator yang dipakai untuk variable system informasi akuntansi menggunakan pendekatan Technology Acceptance Model (TAM) dan alat analisis yang digunakan kebanyakan menggunakan SPSS sedangkan penelitian ini akan menggunakan alat analisis dengan pendekatan Structural Equation Model menggunakan SmartPLS sehingga dapat merefleksikan konstruk yang diuji melalui indikator-indikator secara lebih komprehensif.

\section{TINJAUAN PUSTAKA}

\section{Theory of Acceptance Model (TAM)}

Penelitian ini menggunakan konsep model berketerimaan teknologi (Technology Acceptance Model-TAM) yang dilandasi teori tindakan beralasan (Theory of Reasoned Action-TRA). TAM juga merinci faktorfaktor apa saja yang dapat memengaruhi penerimaan suatu teknologi dalam sistem informasi dan dapat menggambarkan perilaku penggunaan teknologi (Kurniawan et al., 2013) dan (Vidantika \& Putra, 2018). Menurut Surendran (2012) Technology Acceptance Model (TAM) atau Model Penerimaan Teknologi Model TAM telah banyak digunakan untuk membantu memahami dan menjelaskan perilaku pengguna dalam suatu sistem informasi, ada beberapa penelitian yang telah digunakan untuk menguji model dan hasilnya sudah reliabel. Dimana menjelaskan model penerimaan teknologi dan berbagai faktor penting di dalamnya. Penggunaan Technology Accepted Model (TAM) sebagai salah satu landasan teori dalam penelitian ini adalah untuk menganalisis pengaruh penerapan e-commerce dan system informasi akuntansi terhadap minat mahasiswa akuntansi untuk berwirausaha.

\section{Contingency Theory}

Menurut Robbins (2001) contingency theory merupakan pendekatan kepemimpinan yang mendorong pemimpin memahami perilakunya sendiri. Teori ini mengatakan bahwa keefektifan sebuah kepemimpinan adalah fungsi dari berbagai aspek situasi kepemimpinan. Pandangan teori ini dalam organisasi, memandang bahwa dalam penyelesaian masalah organisasi dapat dituntaskan dengan menggunakan 
metode- metode yang sesuai dengan situasi dan kondisi pada saat itu. Contingency theory merupakan perkembangan yang mutakhir dari teori organisasi.

Contingency theory memandang organisasi sebagai sistem terbuka yang memiliki hubungan dengan lingkungan dan lingkungan juga mempengaruhi proses internal organisasi. Dimana organisasi harus mengubah tatanan internal untuk merespon berbagai lingkungan sehingga muncul adagium no one best way to organize. Implikasinya dengan penelitian ini adalah contingency theory akan mampu menjelaskan hubungan keterkaitan antara penerapan dalam penggunaan sistem informasi akuntansi dan keperilakuan yang terjadi di dalam suatu organisasi atau usaha sehingga mempengaruhi untuk berwirausaha.

\section{Pengembangan Hipotesis}

Pengaruh E-Commerce Terhadap Pengambilan Keputusan Mahasiswa Akuntansi Dalam Berwirausaha. Pada dasarnya e-commerce merupakan dampak dari berkembangnya teknologi informasi dan telekomunikasi, sehingga secara signifikan merubah cara manusia melakukan interaksi dengan lingkungan sekitarnya, yang dalam hal ini terkait dengan perdagangan (Mantri, 2007). Hal ini sesuai dengan perilaku penggunaan Technology Accepted Model (TAM) untuk menganalisis pengaruh penerapan e-commerce terhadap minat mahasiswa akuntansi untuk berwirausaha. Begitu dengan contingency theory memandang organisasi sebagai sistem terbuka yang memiliki hubungan dengan lingkungan dan lingkungan juga mempengaruhi proses internal organisasi. Dimana contingency theory akan mampu menjelaskan hubungan keterkaitan antara penerapan dalam penggunaan e-commerce dan keperilakuan yang terjadi di dalam suatu organisasi atau usaha sehingga mempengaruhi untuk berwirausaha

Hal ini didukung hasil penelitian Pramiswari \& Dharmadiaksa (2017), Sari \& Wibawa (2017), Yadewani \& Wijaya (2017), Margareta (2019), Trihudiyatmanto (2019), Wulandari et al., (2020) dan Wahyuni \& Diana (2020) yang menyatakan bahwa e-commerce berpengaruh dan signifikan terhadap pengambilan keputusan untuk berwirausaha. Berdasarkan penjelasan diatas, maka hipotesis yang dapat diambil yaitu:

H1: E-commerce berpengaruh positif dan signifikan terhadap pengambilan keputusan mahasiswa akuntansi dalam berwirausaha Pengaruh Sistem Informasi Akuntansi Terhadap Pengambilan Keputusan Mahasiswa Akuntansi Dalam Berwirausaha

Sistem akuntansi sangat dibutuhkan dalam sebuah bisnis karena dapat membantu dalam pengolahan data sehingga ketika seorang pemimpin atau wirausaha mengambil keputusan, keputusan itu berdasarkan data yang telah ada atau data yang telah dimilki. Technology Accepted Model (TAM) berasal dari teori psikologis untuk menjelaskan 
perilaku pengguna teknologi informasi yang berlandaskan pada kepercayaan, sikap, niat dan hubungan perilaku pengguna Penggunaan Technology Accepted Model (TAM) sebagai salah satu landasan teori dalam penelitian ini adalah untuk menganalisis pengaruh penerapan sistem informasi akuntansi terhadap minat mahasiswa akuntansi untuk berwirausaha. Begitu juga dengan contingency theory memandang organisasi sebagai sistem terbuka yang memiliki hubungan dengan lingkungan dan lingkungan juga mempengaruhi proses internal organisasi. Dimana contingency theory akan mampu menjelaskan hubungan keterkaitan antara penerapan dalam penggunaan sistem informasi akuntansi dan keperilakuan yang terjadi di dalam suatu organisasi atau usaha sehingga mempengaruhi untuk berwirausaha.

$\mathrm{Hal}$ ini didukung hasil penelitian Pramiswari \& Dharmadiaksa (2017), Margareta (2019), Wulandari et al., (2020) dan Wahyuni \& Diana (2020) yang menyatakan bahwa system informasi akuntansi berpengaruh dan signifikan terhadap pengambilan keputusan untuk berwirausaha. Berdasarkan penjelasan diatas, maka hipotesis yang dapat diambil yaitu:

$\mathrm{H} 2$ : Sistem informasi akuntansi berpengaruh positif dan siginfikan terhadap pengambilan keputusan mahasiswa akuntansi dalam berwirausaha

\section{Rerangka Konseptual}

Berdasarkan penjabaran pada latar belakang, rumusan masalah, referensi dari penelitian terdahulu serta tinjauan pustaka, maka disusun rerangka konseptual penelitian ini, dapt dilihat pada gambar 1

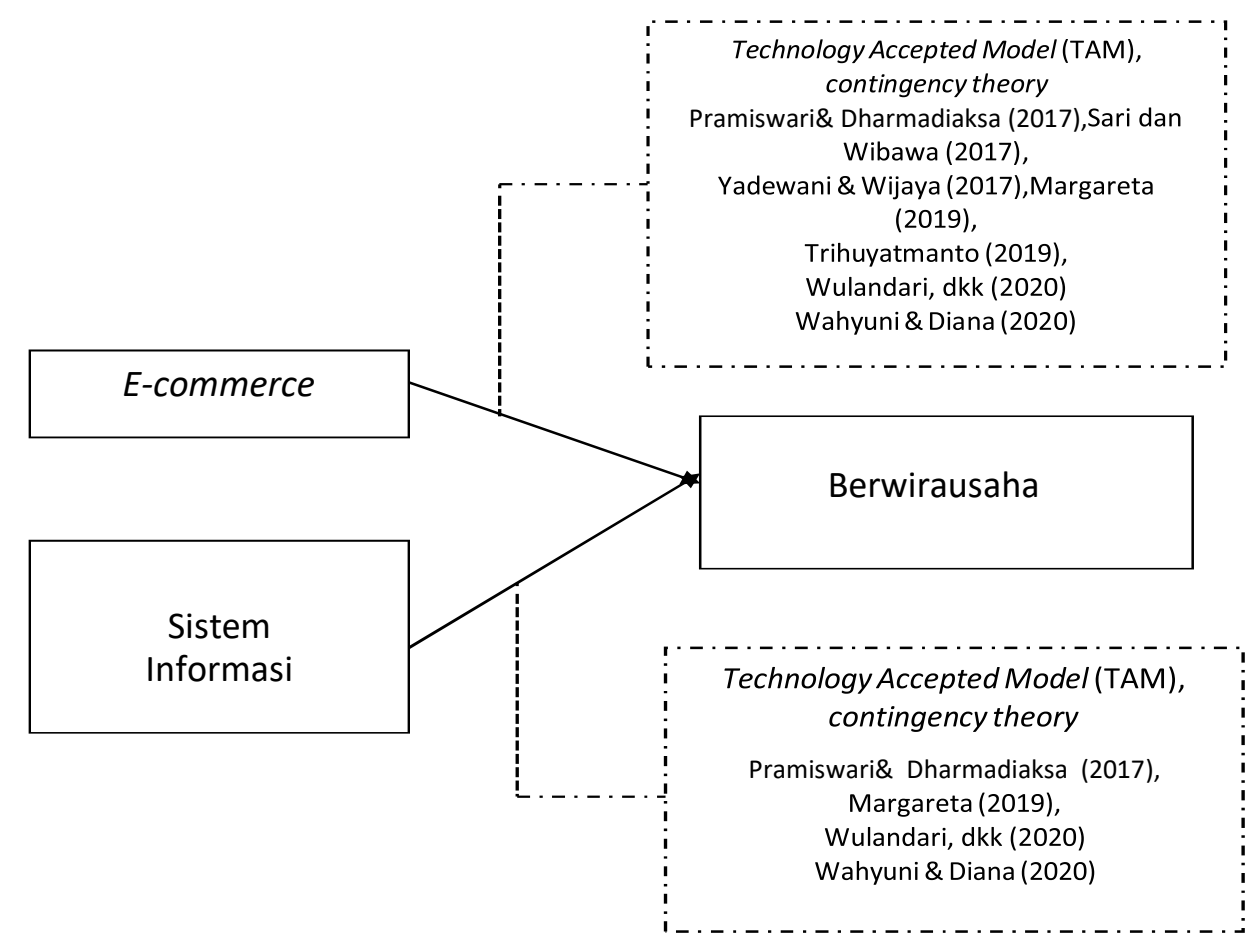


Nurabiah, dkk : E-Commerce Dan Sistem Informasi Akuntansi Sebagai Faktor...................

Gambar 1. Rerangka Konseptual 


\section{METODE PENELITIAN}

\section{Jenis Penelitian}

Jenis penelitian yang digunakan dalam penelitian ini adalah penelitian asosiatif. Dimana variabel yang dipengaruhi (dependen) yaitu e-commerce dan system informasi akuntansi dan variabel yang mempengaruhi (independen) yaitu pengambilan keputusan mahasiswa akuntansi dalam berwirausaha

\section{Populasi dan Sampel Penelitian}

Populasi dalam penelitian ini adalah seluruh mahasiswa S1 jurusan akuntansi PTN dan PTS di Kota Mataram. Teknik pengambilan sampel yang digunakan adalah purposive sampling yaitu mahasiswa akuntansi yang sudah mengambil mata kuliah kewirausahaan dan system informasi akuntansi dengan total sampel 210 mahasiswa

Instrumen Penelitian

Instrumen penelitian ini disusun berdasarkan indikator yang terkandung dalam e-commerce yaitu mudah diakses, transaksi mudah dilakukan, proses pelayanan cepat dan aman, dan Permodalan e- commerce tidak terlalu tinggi. Sistem informasi yaitu perceived usefulness, perceived ease of use, attitute towards behavior, behavioral intention dan subjective norm. Dan minat berwirausaha terdiri dari jiwa kepemimpinan, perbandingan dengan pekerjaan lain, tidak ada ketergantungan, membantu lingkungan social, dan berorientasi pada masa depan

\section{Prosedur Analisis Data}

Penelitian ini menggunakan metode analisis data dengan menggunakan software SmartPLS versi 3.2.1.m3 yang dijalankan dengan media computer, terdapat beberapa langakah dalam menyusun model PLS : 1) Merancang inner model. 2) Merancang outer model. 3) Merekontruksi diagram jalur. 4) Merekontruksi diagram jalur ke persamaan. 5) Estimasi koefisien jalur dan nilai loading. 6) Evaluasi goodness of fit. 7) Pengujian hipotesis.

\section{Deskripsi Sampel Penelitian}

\section{HASIL DAN PEMBAHASAN}

Jumlah kuesioner yang disebar lewat google form sebanyak 210 dari 2 lokasi. Sedangkan kuesioner yang dikembalikan dan diolah sebanyak 142 dengan tingkat pengembaliannya sebesar 68\% sehingga total kuesioner yang tidak dikembalikan sebanyak 68 kuesioner. Kuesioner yang tidak dikembalikan cukup banyak disebabkan covid-19 sehingga tidak bisa dipantau secara langsung. 


\section{Analisis Data Uji Validitas Convergent Validity}

Convergent Validity dalam PLS dengan indikator reflektif dinilai berdasarkan loading factor (korelasi antara skor item/skor komponen dengan skor konstruk) indikator-indikator yang mengukur konstruk tersebut. Rule of thumb yang biasanya digunakan untuk mengukur validitas konvergen adalah outer loading $>0,7$, jika nilai loading factor 0,5 sd 0,6 masih dianggap cukup (Ghozali, 2011). Nilai loading factor dalam penelitian ini menunjukkan sudah memenuhi syarat di atas 0,5 dan yang tidak memenuhi syarat sudah dieliminasi.

Gambar 2 Model Struktural sesudah dieliminasi

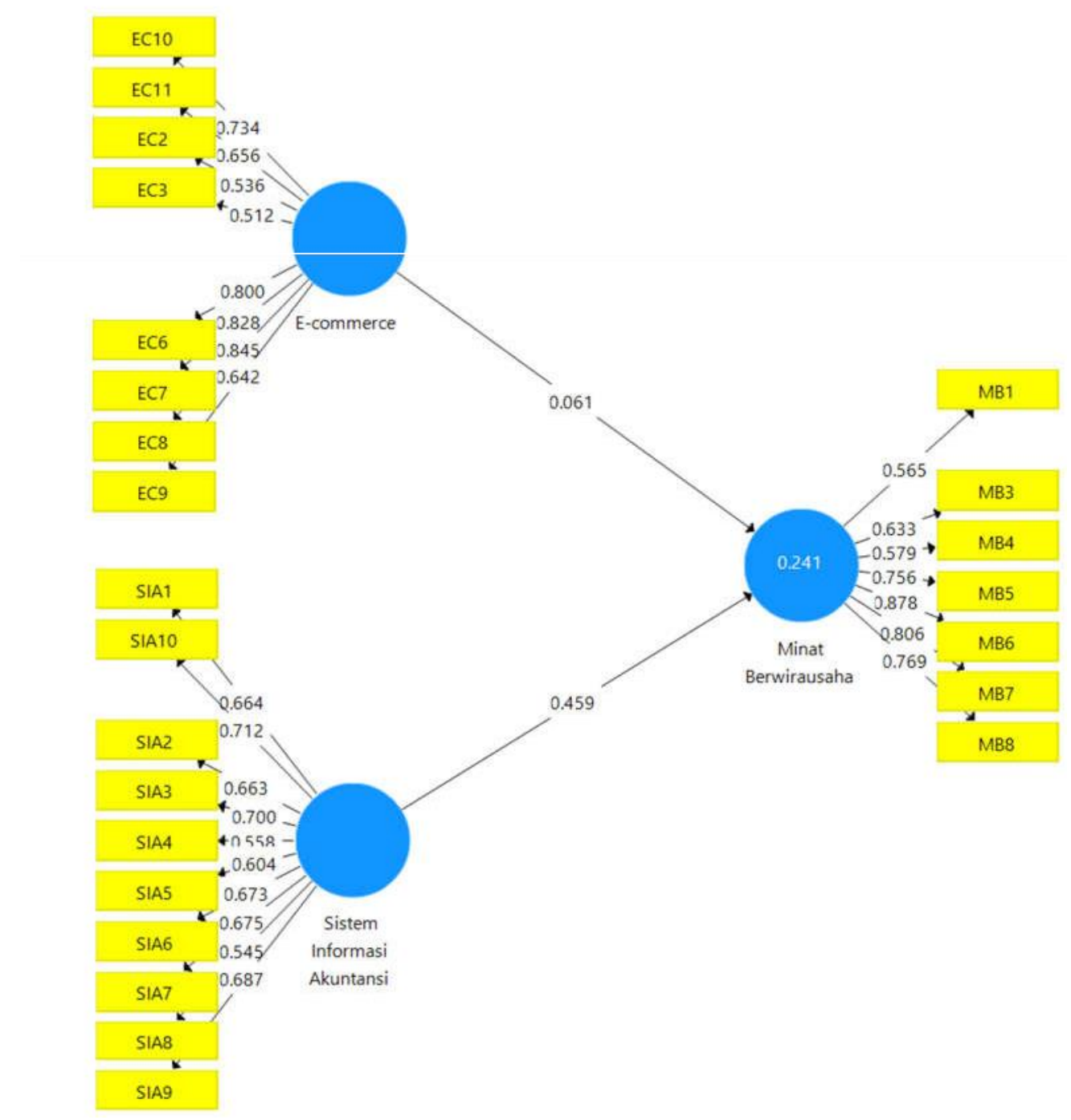




\section{Uji Reliabilitas}

Uji reliabilitas dapat dilihat dari nilai composite reliability dan cronbach's alpha. Untuk dapat dikatakan suatu konstruk yang reliabel, maka nilai cronbach's alpha harus $>0,7$ dan nilai composite reliability harus $>0,7$. Dan hasilnya memenuhi syarat sudah di atas 0,7 .

\section{Uji Hipotesis}

Dalam menguji hipotesis, dasar yang digunakan terdapat pada output result for inner weight berikut ini:

Tabel 1. Result For Inner Weight Path Coefficient (Mean, STDEV, T-Values)

\begin{tabular}{lccc} 
& $\begin{array}{c}\text { Sampel } \\
\text { Asli (O) }\end{array}$ & $\begin{array}{c}\text { T Statistik } \\
(|\mathrm{O} / \mathrm{STDEV}| \\
)\end{array}$ & $\begin{array}{c}\text { T- } \\
\text { table }\end{array}$ \\
\hline $\begin{array}{l}\text { E-commerce-> } \\
\text { Minat Berwirausaha }\end{array}$ & 0,061 & 0,856 & 1.655 \\
\hline $\begin{array}{l}\text { Sistem Informasi } \\
\begin{array}{l}\text { Akuntansi -> Minat } \\
\text { Berwirausaha }\end{array}\end{array}$ & 0,459 & 6,42 & 1.655 \\
\hline
\end{tabular}

Sumber: Data Primer diolah 2020

Berdasarkan tabel 1, dapat kita lihat bahwa variabel yang memiliki nilai t-statistik di atas 1,655 yaitu variabel system informasi akuntansi terhadap minat berwirausaha 6,42 artinya system informasi akuntansi berpengaruh positif signifikan terhadap minat berwirausaha, sedangkan nilai t-statistik di bawah 1,655 yaitu variabel e-commerce terhadap minat berwirausaha 0,856 artinya e- commerce berpengaruh positif tidak signifikan terhadap minat berwirausaha.

\section{Pembahasan}

E-Commerce Berpengaruh Positif dan Signifikan Terhadap Pengambilan Keputusan Mahasiswa Akuntansi Dalam Berwirausaha

Hasil PLS menunjukkan bahwa terdapat pengaruh positif tidak signifikan antara e-commerce terhadap pengambilan keputusan mahasiswa akuntansi dalam berwirausaha. Artinya penelitian ini membuktikan bahwa mahasiswa jurusan akuntansi se kota Mataram sudah memanfaatkan penggunaan e-commerce walaupun belum maksimal, hal ini bisa dilihat bahwa persentase alasan mahasiswa akuntansi menggunakan e-commerce sebagian besar masih kurang dari $50 \%$, itu artinya responden menggunakan e-commerce dengan berbagai kelebihannya tetapi belum signifikan. Responden masih ragu terutama 
dalam hal biaya yang digunakan untuk e-commerce masih mahal, hal ini terlihat hanya $26,1 \%$ yang menjawab biaya yang dibutuhkan penggunaan e-commerce lebih murah dari yang lain.

Selain itu cukup banyak responden dalam melakukan transaksi jual beli tidak menggunakan e-commerce. Hal ini terlihat jawaban responden penggunaan e-commerce masih cukup banyak yang menggunakan sosial media (facebook/ instagram/Twitter) sebesar 76,4\% artinya responden dalam penggunaan e-commerce masih relative sedikit. Dimana ecommerce merupakan bisnis elektronik ke seluruh jaringan bisnis dunia, meliputi seluruh proses dari pemasaran, penjualan, pengiriman, pelayanan, dan pembayaran para pelanggan dan pengembangan, tidak hanya membeli dan menjual secara online. Sistem e-commerce bergantung pada sumber daya internet dan teknologi informasi lainnya. Jadi, secara garis besar pengertian e commerce ini bukan hanya meliputi aktivitas perniagaan saja. Tapi juga mencakup kolaborasi dengan mitra bisnis, client service, lowongan pekerjaan, dan sebagainya. Di samping memanfaatkan teknologi digital, e commerce ini juga membutuhkan database, e-mail, dan juga teknologi lain yang non internet. Misalnya saja dalam mengirim barang, dan caramembayar produk dari e commerce. Kemungkingkan responden agak berat dengan hal-hal tersebut.

Hasil ini juga dapat dilihat dari hasil penyebaran kuesioner cukup banyak responden menyatakan bahwa e-commerce tidak terlalu mudah digunakan, tidak terlalu aman, dan membutuhkan biaya yang cukup tinggi. Sehingga dalam penggunaan e- commerce dalam berwirausaha nanti responden masih ragu-ragu dengan adanya keterbatasan dalam menggunakan e-commerce, seperti ketergantungan yang sangat kuat pada teknologi informasi dan komunikasi, urangnya undang-undang yang memadai untuk mengatur kegiatan e-commerce, baik nasional maupun internasional, budaya pasar yang menolak perdagangan elektronik (pelanggan tidak bisa menyentuh atau mencoba produk), rawannya melakukan transaksi bisnis online, dan warna dan kualitas produk yang dijual belum tentu sama antara foto yang ditampilkan di website dengan produk asli

Selain itu, hasil penelitian ini didukung teori Technology Acceptance Model (TAM) yang menjelaskan tingkat keyakinan individu daam penggunaan sistem informasi tertentu akan meningkatkan keterlibatannya sebagai penggunadan meyakini bahwa keterlibatan dalam menggunakan e-commerce dalam mengembangkan kewirausahaannya nanti walaupun masih hati- hati dalam menggunakan e-commerce. Hasil penelitian ini tidak konsisten dengan penelitian terdahulu yang dilakukan Pramiswari dan Dharmadiaksa (2017), Sari dan Wibawa (2017), Yadewani dan Wijaya (2017), Margareta (2019), Trihuyatmanto (2019), Wulandari, et al (2020) dan Wahyuni dan Diana (2020) yang menyatakan bahwa e-commerce berpengaruh dan signifikan terhadap pengambilan keputusan untuk 


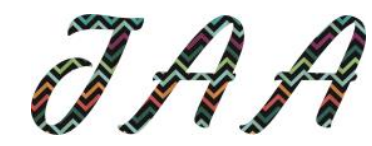

Vol. 5, No. 2, April 2021

berwirausaha. Sistem Informasi Akuntansi Berpengaruh Positif Dan Signifikan Terhadap Pengambilan Keputusan Mahasiswa Akuntansi Dalam Berwirausaha

Hasil PLS menunjukkan bahwa terdapat pengaruh positif signifikan antara sistem informasi akuntnasi terhadap pengambilan keputusan mahasiswa akuntansi dalam berwirausaha. Artinya penelitian ini membuktikan bahwa mahasiswa jurusan akuntansi se kota Mataram sudah memanfaatkan penggunaan sistem informasi akuntansi seperti software MYOB, Accurate, Zahir Accounting dan excel akuntansi sehingga sudah merasakan manfaat dari penggunaan sistem informasi akuntansi dan itu membuat mereka yakin kalau berwirausaha nanti responden akan menggunakan system informasi akuntansi untuk mengelola keuangan dan menghasilkan laporan keuangan. Hal ini bisa dilihat bahwa persentase alasan mahasiswa akuntansi menggunakan sistem informasi akuntnasi sebagian besar yaitu 76,8\%, dimana responden merasakan manfaat dari penggunaan sistem informasi akuntansi salah satunya efektif dan efisien. Artinya, adanya penerapan sistem informasi akuntansi dapat dipahami dan diterapkan secara mudah, pekerjaan dapat diselesaikan secara tepat waktu setelah adanya penerapan sistem informasi akuntansi, ketelitian dalam menyelesaikan pekerjaan meningkat setelah adanya penerapan sistem informasi akuntansi, terdapat dukungan dalam menyelesaikan pekerjaan dengan menggunakan sistem informasi akuntansi, proses input data dalam sistem informasi akuntansi yang diterapkan dapat dilakukan dengan mudah, proses pengeditan data dalam sisteminformasi akuntansi yang diterapkan dapat dilakukan dengan mudah, dan proses output data dalam sistem informasi yang diterapkan dapat dilakukan dengan mudah. Sehingga itu semua memunculkan keinginan untuk berwirausaha dengan adanya kebaikan dari sistem informasi akuntansi.

Hal ini juga diperkuat dari hasil penyebaran kuesioner tentang persepsi penggunaan sistem informasi akuntansi dimana sebanyak 78,7\% responden menilai bahwa system informasi akuntansi bermanfaat dan mereka akan menggunakan jika berwirausaha nanti, hal ini ditandai dengan perceived usefulness (persepsi kegunaan sistem informasi akuntansi sangat berguna), perceived ease of use (persepsi kemudahan dalam menggunakan sistem informasi akuntansi sangat mudah), attitude towards behavior (perilaku menggunakan system informasi dalam berwirausaha sangat mumpuni), behavioral intention (keingginana menggunakan sistem informasi dalam berwirausaha sangat ingin), dan subjective norm (factor luar yang sangat mempengaruhi mereka dalam menggunakan sistem informasi akuntansi untuk berwirausaha nanti).

Selain itu, hasil penelitian ini didukung teori Technology Acceptance Model (TAM) yang menjelaskan tingkat keyakinan individu daam penggunaan sistem informasi tertentu akan meningkatkan keterlibatannya sebagai pengguna dan meyakini bahwa keterlibatan dalam menggunakan 
sistem informasi akuntansi dalam mengembangkan kewirausahaannya dengan merasakan manfaat dari system informasi akuntansi tersebut . Selain itu mendukung contingency theory yang dimana mampu menjelaskan hubungan keterkaitan antara penerapan dalampenggunaan sistem informasi akuntansi dan keperilakuan yang terjadi di dalam suatu organisasi atau usaha sehingga mempengaruhi untuk berwirausaha. Hasil penelitian ini konsisten dengan penelitian terdahulu yang dilakukan oleh Pramiswari dan Dharmadiaksa (2017), Margareta (2019), Wulandari et al., (2020) dan Wahyuni dan Diana (2020) yang menyatakan bahwa system informasi akuntansi berpengaruh dan signifikan terhadap pengambilan keputusan untuk berwirausaha.

\section{Kesimpulan}

\section{KESIMPULAN DAN SARAN}

Berdasarkan analisis data sebelumnya, maka dapat disimpulkan hal-hal sebagai berikut:

1. E-commerce berpengaruh positif tidak signifikan terhadap pengambilan keputusan mahasiswa akuntansi dalam berwirausaha.

2. Sistem informasi akuntansi berpengaruh positif signifikan terhadap pengambilan keputusan mahasiswa akuntansi dalam berwirausaha

\section{Implikasi Penelitian Implikasi Teoritis}

Implikasi teoritis dari penelitian ini yaitu dapat memberikan kontribusi pada pengembangan teori technology acceptance model (TAM) dan contingency theory pada kegiatan perkuliahan dengan kondisi yang ada di lapangan. Dimana teori Technology Acceptance Model (TAM) memberikan keyakinan individu dalam penggunaan sistem informasi tertentu akan meningkatkan keterlibatannya sebagai pengguna dan meyakini bahwa keterlibatan dalam menggunakan sistem informasi akuntansi dalam mengembangkan kewirausahaannya dengan merasakan manfaat dari sistem informasi akuntansi tersebut. Selain contingency theory mampu menjelaskan hubungan keterkaitan antara penerapan dalam penggunaan sistem informasi akuntansi dan keperilakuan yang terjadi di dalam suatu organisasi atau usaha sehingga mempengaruhi untuk berwirausaha.

\section{Implikasi Praktis}

Hasil penelitian ini digunakan sebagai masukan bagi dosen dan calon dosen untuk selalu membenahi diri sehubungan dengan pengajaran yang telah dilakukan dan prestasi belajar mahasiwa yang telah dicapai dengan memperhatikan metode pembelajaran yang tepat dan motivasi belajar mahasiwa untuk menjadi enterpreneur 


\section{Implikasi Kebijakan}

Hasil penelitian ini diharapkan memberi kontribusi implikasi kebijakan perguruan tinggi khususnya jurusan akuntansi fakultas ekonomi dan bisnis melalui pembelajaran e-commerce dan sistem informasi akuntansi yang selaras dengan dunia kerja dan enterpreunership sehingga mahasiswa bisa secara mandiri membuka usaha baru. Serta melibatkan para mahasiwa untuk mengikuti semua event - event yang berhubungan dengan kewirausahaan selain itu juga di berikan kesempatan untuk mengikuti berbagai pelatihan kewirausahaan baik yang bersifat lokal maupun nasional. Selain itu perguruan tinggi bisa turut mendukung program pemerintah yakni meningkatkan jumlah wirausahawan untuk mendukung visi Indonesia menjadi Negara maju di tahun 2045.

\section{Saran dan Keterbatasan Penelitian}

Di dalam penelitian ini terdapat beberapa keterbatasan yang dapat dijadikan sebagai referensi atau kebaruan dalam penelitian mendatang yang akan mengangkat tema yang sama, beberapa diantaranya, yaitu:

1. Penelitian ini perlu dikembangkan lagi untuk mendapatkan hasil empirik lebih kuat, yaitu dengan menambah variabel lainnya yang dapat mempengaruhi minat mahasiswa berwirausaha seperti strategi pemasaran, pendidikan kewirausahaan, ekspektasi pendapatan, motivasi internal dan ekternal, keterampilan berwirausaha, dan kepribadian.

2. Pada penelitian ini masih berada pada tingkat minat berwirausaha pada responden yang masih berstatus mahasiswa. Untuk penelitian selanjutnya dapat meneliti lebih lanjut ke tingkat taking action untuk berwirausaha dengan responden alumni sehingga diketahui apakah ada perbedaan persepsi ketika masih menjadi mahasiswa dan ketika sudah siap di dunia kerja (alumni) mengingkat ketika masih mahasiswa idealisme dalam pemilihan karir cukup tinggi.

3. Penelitian ini hanya menggunakan mahasiswa akuntansi di kota Mataram sebagai objek penelitian, disarankan pada penelitian selanjutnya untuk menambah objek penelitian misalnya seluruh mahasiwa akuntansi se Nusa Tenggara Barat agar memperluas hasil penelitian.

\section{DAFTAR PUSTAKA}

Bodnar, G. ., \& Hopwood, W. S. (2013). Sistem Informasi Akuntansi (11th ed.). Jakarta: Salemba Empat.

BPS. (2020). Berita resmi statistik. Www.Bps.Go.Id. https://www.bps.go.id/website/materi_ind/materiBrsInd20200505115439.pdf

Ghozali, I. (2011). Structural Equation Modeling Metode Alternatif dengan Partial Least Square (PLS) (3rd ed.). Semarang: Undip. 
Kurniawan, D., Semuel, H., \& Japarianto, E. (2013). Analisis Penerimaan Nasabah terhadap Layanan Mobile Banking dengan Menggunakan Pendekatan Technology Acceptance Model dan Theory of Reasoned Action. Jurnal Manajemen Pemasaran, 1(1), 1-13.

Mantri, B. H. (2007). Perlindungan hukum terhadap konsumen dalam transaksi e-commerce. Jurnal Law Reform, 3(1), 1-21. https://doi.org/https://doi.org/10.14710/Ir.v3i1.12340

Margareta, I. P. (2019). Pengaruh E-Commerce dan Penggunaan Sistem Informasi Akuntansi dalam Pengambilan Keputusan untuk Berwirausaha (Studi Kasus pada Perguruan Tinggi .... http://eprints.ums.ac.id/id/eprint/77404

Pramiswari, D. A. A., \& Dharmadiaksa, I. B. (2017). Pengaruh ECommerce Dan Penggunaan Sistem Informasi Akuntansi Dalam Pengambilan Keputusan Untuk Berwirausaha. E-Jurnal Akuntansi, 2017(1), 261-289.

Prihadi, D., \& Susilawati, A. D. (2018). Pengaruh Kemampuan ECommerce dan Promosi di Media Sosial terhadap Kinerja Pemasaraan. Benefit: Jurnal Manajemen Dan Bisnis, 3(1), 15. https://doi.org/10.23917/benefit.v3i1.5647

Robbins, S. P. (2001). Perilaku Organisasi: Konsep, Kontroversi, dan Aplikasi (8 Jilid 1). Jakarta: Prenhallindo.

Romney, N. B., \& Steinbert, P. J. (2017). Accounting Information System (13th ed.). The New Jersey: Pearson Practice Hall.

Sari, D. C. K., \& Wibawa, S. C. (2017). Pengaruh Penggunaan Ecommerce Dalam Proses Penjualan Terhadap Minat Berwirausaha Siswa SMK Ngraho. IT-Edu, 2(01), 16-23.

Surendran, P. (2012). Technology Acceptance Model: A Survey of Literature. Internatiomal Journal of Business and Social Research (IJBSR), 2 No.4, 175-178. https://doi.org/https://doi.org/10.18533/ijbsr.v2i4.161

Suryaman, M. (2006). Minat Berwirausaha pada Mahasiswa Pendidikan Teknik Elektro Fakultas Teknik Universitas Negeri Semarang. http://digilib.unnes.ac.id/gsdl/collect/skripsi/archives/HASH01b0/98 96e0e8.dir/doc.pdf

Trihudiyatmanto, M. (2019). Membangun Minat Berwirausaha Mahasiswa Dengan Pengaruh Faktor E-Commerce, Pengetahuan Kewirausahaan dan Gender. Jurnal Penelitian Dan Pengabdian Kepada Masyarakat UNSIQ, 6(2), 93-103. https://doi.org/10.32699/ppkm.v6i2.678

Vidantika, P. N. C. D., \& Putra, I. M. P. D. (2018). Analisis TAM Terhadap Sikap Penggunaan Sistem Informasi Akuntansi Penggajian di PT Garuda Indonesia Station DPS Fakultas Ekonomi dan Bisnis Universitas Udayana ( Unud ), Bali , Indonesia Fakultas Ekonomi dan Bisnis U. E-Jurnal Akuntansi Universitas Udayana, 24(2), 1105- 
1134.

https://doi.org/https://doi.org/10.24843/EJA.2018.v24.i02.p11

Wahyuni, E. T., \& Diana, N. (2020). E-commerce dan sistem informasi akuntansi sebagai faktor pendorong pengambilan keputusan mahasiswa akuntansi untuk berwirausaha. E-Jurnal Ilmiah Riset Akuntansi, 09(03), 93-115.

Wulandari, Maslichah, \& Sudaryanti, D. (2020). pengaruh e-commerce dan penggunaan sistem informasi akuntansi pada pengambilan keputusan dalam berwirausaha di Sanggam Mart Kabupaten Balangan. E-Jra, 47-57. http://riset.unisma.ac.id/index.php/jra/article/view/6185/5089

Yadewani, D., \& Wijaya, R. (2017). Pengaruh E-Commerce Terhadap Minat Berwirausaha. RESTI (Rekayasa Sistem Dan Teknologi Informasi, 1(1), 64-69.

https://doi.org/https://doi.org/10.29207/resti.v1i1.6 